\title{
Industry of the Region in 1941- 1945: Problems of the Reorientation to "A War Footing"
}

\author{
Almaz Rafisovich Gapsalamov \\ Elabuga Institute of Kazan Federal University, 89, Kazanskaya st., Elabuga 423600, \\ Republic of Tatarstan, PhD, Senior Lecturer \\ Email: Gapsalamov@yandex.ru
}

Doi:10.5901/mjss.2015.v6n3p189

Abstract

Investigation of the problems connected with functioning of the regional systems and development of their operating overhead are becoming of current importance. This is due to the crisis processes that occur in the country and the world in recent decades. The used methods of meeting them are not effective. It is necessary to create new ways of maintaining high economic growth and this explains an increasing interest on issues related to the searching for "growth points" of the modern economy. And the key aspect that determines the gradual process of development of any country, from our point of view, is realization of organizational changes. References to such kinds of issues made by historians are not accidental. The problems connected with the origin and evolution of the economic authorities (public institutions) in a particular historical situation, their organizational structure and activities are under study. In general, the historical experience of the previous reforms nowadays should be an effective basis for the following organizational changes. In this respect, the problems of the development of the industrial management system in the individual regions of the USSR during the Second World War (for Russia - the Great Patriotic War), as the experience of successful reform of the economy during the system crises tend to be interesting for investigation. In a short period of time an agrarian republic transformed into a predominantly industrial region contributing to its further powerful rise.

Keywords: World War II, Russia, the Republic of Tatarstan, region, industry

\section{Introduction}

The modern model of the Russian economy can no longer be a guarantee of stability and progressive development in future. In recent years economic growth rates are inclined to shift into low gear and sluggish development is observed. Besides western sanction actions only add negative notes. The above-listed causes searching for the mechanisms of impact on the existing system, which will give her a dispersing effect.

In this regard it is necessary to analyze the impact of government reforms on the structural elements of the system which at certain stages of development of Russia gave a positive effect and contributed to the accelerated growth of the domestic economy.

The relevance of this work is determined by the fact that the questions of regional economy and the ensuing problems of management of its branches, the development of management personnel are hardly reflected in the theoretical studies. That is why in this article the features of the industrial development in the Republic of Tatarstan (Tatar ASSR) during the Great Patriotic War are observed in the historical sequence.

The objective of the paper is the analysis of organizational adjustments in industrial management of the Republic of Tatarstan (the region of Russia) in the period of the Great Patriotic War (1941-1945ss) and their influence in the economic growth.

\section{Research Methodology}

The methodology of the paper is based on the approaches, concepts and methods of scientific knowledge. The author relies on the idea of dialectical development which is the foundation for such kind of approaches like historical method, objectivity and systemacity. When defining a method and process under consideration the certain order has been kept for its consistent study taking into account the characteristics of its development under the influence of different external and internal factors.

The methodological foundation of this paper is an approach based on the use of the principle of historicism. The phenomena and processes in the context of their spatial-temporal dependence in close relationship with other socioeconomic, political phenomena and processes and with the certain historic circumstances are reviewed on its basis. Guided by this principle the author tries to examine the evolution of administration agencies of Tatar ASSR industry (the 
Republic of Tatarstan) in the dynamics of management system development of the industry in the USSR during the war.

The principle of scientific objectivity involves an impartial consideration of the research subject and also suggests the analysis of the set of historical facts in their contradictory relationship and interaction which is the important factor for the subsequent formulation of judgments about the challenges under the investigation and the formation of views on historical events and phenomena.

The principle of objectiveness in the study of the activity of Central and local bodies of state power and administration for the implementation of economic policies helps to avoid some categorical judgments and conclusions, to consider the positive and negative trends in the development of the region in 1941 - 1945ss. In particular, when analyzing historiography and source material, the author avoids competitive assessments in the matter of organizational activities of the Soviet authorities in the field of restructuring of the management industry apparatus of the Republic during the war. These principles have been used in conjunction with the methodological approaches of scientific knowledge, especially with problem-chronological approach.

\section{Results}

We propose the main thesis that World War II despite serious difficulties, destruction, loss of life, etc., at the same time, produced a progressive effect on the development of individual regions. In particular, the Republic of Tatarstan (the modern republic of the Russian Federation, in the period in question - Tatar Autonomous Soviet Socialist Republic) was able to grow from an agrarian to a predominantly industrial region of the Soviet Union.

Considering the conditions for the development of the Soviet economy at the beginning of the war it should be mentioned that at this period a model of industrial management of the country was built, one of the main advantages of which was strict discipline and responsibility of all control system objects. At the end of June 1941the Council of People's Commissars of the USSR adopted the first plan of the wartime - "mobilization plan of national economy" for the III quarter of 1941.The plan was one of the most important measures for the restructuring of the Soviet economy and putting it on a war footing and especially the concentration of capital works and material resources for the construction of defense enterprises in the Volga region, the Urals and Western Siberia. August 16, 1941 the Council of People's Commissars of the USSR and the CPSU (b) submitted by the State Planning Committee passed the military-economic plan for the IV quarter of 1941 and 1942 for such regions as the Volga, the Urals, Western Siberia, Kazakhstan, Central Asia. (Gilmanov 1977, p. 65; The Directives of the CPSU 1957, p. 707-712) The adoption of these plans meant that the brunt of the economic support of the war in these conditions laid down in the east of the country, including the Volga region. The restructuring of the industry in these areas on a war footing had to create conditions of getting more productive effect of smaller industrial potential.

Thereupon the Tatar ASSR became one of the most important arsenals of the country to repulse enemy's attacks. The newspaper "Red Tatarstan" wrote that "it is impossible to find a plant, a factory or a workshop in the country that doesn't execute the front-line orders in a varying degree ". (The Red Tatarstan 1942 January)

The resolution of the joint plenum of the Tatar Regional Committee and the Kazan city committee of the CPSU (b) on November 13, 1941 makes clear the problems facing the republic's industry at the initial stage of the war - "to ensure the unconditional implementation of plans of IV quarter 1941 achieving strict adherence to the daily schedules and rhythm of each company, workshop and plot; to organize the work of enterprises in such a way to maximize the use of existing equipment, to organize the production process properly; to improve strongly the management of the Stakhanovite movement in the factories; to render assistance with redundant equipment, materials in order to perform the military tasks; to accommodate all workers, engineers and technical workers coming from the evacuated plant at the expense of compacting the population of Kazan as soon as possible... ". (Tatarstan during 1963, p. 69-70)

The reorientation prepossess of the industry to military production began in Kazan and its regional centers, new branches of industry (instrument, rubber, chemical-pharmaceutical and etc.) (Tatarstan during 1963, p. 91-92) appeared and were rapidly developing, new enterprise come into service.

At the same time the government began to close economically inefficient enterprises. It was decided to eliminate the Kazan state sago plant "Komsomolets" (the journals of the Council of National Commissioners of Tatarstan on October 7, 1941 number 49), mineral water plant "Izhevsk Source" (the resolution of the Council of National Commissioners TASSR on November 20, 1941 number 570). As for the latter enterprise the decision was reconsidered and it was transferred from the federal to the local submission. (NA TR. Collection. P-6292. Inventory 1. File 286. Leaf 187, 195, 212)

A rigid daily schedule was put into operation in all the enterprises of the republic that, in turn, improved intrafactory planning, forced to mobilize domestic resources with greater persistence and to use all production facilities. (The Red 
Tatarstan 1942 July)

At the time of the reorientation of the local industry to the military regime, the country began the reception, location and launching processes of the evacuated enterprises. Over 70 companies were located in the territory of the republic during the war. Large engineering, instrument-making enterprises, Gorbunov aircraft factory were evacuated to Kazan in the summer and autumn of 1941. Moscow confectionery factory "Bolshevik" was evacuated to the village Morkvashi of Verkhneuslonsky district; tobacco factory "Ducat" - to Kazan, cotton factories and many others to Yelabuga, Mamadysh and Naberezhnye Chelny. Only in Stalin (now the Volga) district of Kazan were located five major industries, five central committees, the People's Commissariat of Food Industry, three procurement agencies, one agricultural industry artel. For their location the Executive Committee of the District Council allocated 15 thousand square meters of the production space, 6 thousand square meters of storage facilities, three car garage, two rooms for workshops plants. (Gilmanov 1977, p. 70-71) The list of companies that were evacuated to the Tatar ASSR only in 1941are enumerated in the table №1.

Table №1. The list of companies that were evacuated to the Tatar ASSR. in 1941. (NA TR. Col. P-7233. Inv. 1. F. 4666. L. 115; NA TR. Col. P-4580. Inv. 1. F. 4966. L. 1, 2, 4)

\begin{tabular}{|c|c|}
\hline People's commissariats & Enterprises \\
\hline \multicolumn{2}{|l|}{ Enterprises of the Union submission } \\
\hline People's Commissariat of Food Industry of the USSR & $\begin{array}{l}\text { - Confectionery Factory "Bolshevik" } \\
\text { - Tobacco Factory "Ducat" } \\
\text { - Tobacco Factory of Vyborg }\end{array}$ \\
\hline People's Commissariat of Public Health of the USSR & - Plant dental burs \\
\hline People's Commissariat of Agriculture of the USSR & $\begin{array}{l}\text { - Biofactory № } 2 \\
\text { - Engine service plant }\end{array}$ \\
\hline People's Commissariat of Industrial Materials of the USSR & - Sleeper impregnation plant \\
\hline People's Commissariat of General Engineering of the USSR & $-2^{\text {nd }}$ watch factory \\
\hline People's Commissariat of Textile Industry of the USSR & $\begin{array}{l}\text { - Krenholm Manufacturing Company } \\
\text { - «Proletarian vanguard» factory }\end{array}$ \\
\hline Foreign departmental & $\begin{array}{l}\text { - Machine accounting factory } \\
\text { - Photographic paper factory № } 7 \\
\text { - Copying factory }\end{array}$ \\
\hline People's Commissariat of River Craft of the USSR & $\begin{array}{l}\text { - Repair yard of Voznesensky } \\
\text { - «Communist International» repair yard }\end{array}$ \\
\hline People's Commissariat of Rubber Industry of the USSR & $\begin{array}{l}\text { - Pilot-production plant } \\
\text { - «Red ruberer» factory }\end{array}$ \\
\hline People's Commissariat of Wood Industry of the USSR & - Parfinsk plywood plant \\
\hline \multicolumn{2}{|l|}{ Enterprises of federative submission } \\
\hline People's Commissariat of Motor Transport of the RSFSR & - Bemesk autogarage equipment factory \\
\hline People's Commissariat of Light Industry of the RSFSR & - Ribbon-loom and dress factory № 3 \\
\hline People's Commissariat of Local Industry of the RSFSR & - Bakovsky rubber plant \\
\hline People's Commissariat of Agriculture of the RSFSR & - Gomel wax foundation plant \\
\hline People's Commissariat of Industrial Building Materials of the RSFSR & $\begin{array}{l}\text { - Glasswork «Friendly climb» } \\
\text { - Ivotsk glasswork }\end{array}$ \\
\hline \multicolumn{2}{|l|}{ Enterprises of local submission } \\
\hline People's Commissariat of Light Industry of the TASSR & $\begin{array}{l}\text { - Shoe factory «Labour» } \\
\text { - Spinning and knitting factory } \\
\text { - Technical felt factory } \\
\text { - Leather factory « Red giant » } \\
\text { - Bitsevksy valeno-felt shoe factory } \\
\text { - Klintsovsky shoe factory }\end{array}$ \\
\hline People's Commissariat of Food Industry of the TASSR & $\begin{array}{l}\text { - Chocolate factory shop "Red October" } \\
\text { - Confectionery plant «Spartak» } \\
\text { - Fruitwinery plant } \\
\text { - Vyborg confectionery factory }\end{array}$ \\
\hline People's Commissariat of Wood Industry of the TASSR & - Vitebsk instrumental furniture factory \\
\hline People's Commissariat of Local Industry of the TASSR & $\begin{array}{l}\text { - Font foundry factory } \\
\text { - Vitebsk brickyard }\end{array}$ \\
\hline People's Commissariat of Dairy and Meat Industry of the TASSR & - Bryansk municipal dairy plant \\
\hline
\end{tabular}


Some of the evacuated to the republic enterprises merged with the same type of local enterprises strengthening their production capacity and some were transferred to the other departments. Due to the transfer of haberdashery and harmonica factories to the People's Commissariat of Light Industry of the RSFSR, Tatpolygraph - to the printing industry management of the Council of National Commissioners of the TASSR and the writing machine plant to the People's Commissariat of Ammunition of the USSR, 2 enterprises were directly subordinate to the People's Commissariat of Local Industry of the TASSR: Tatmetroves and the peat factory of Kazan.

The number of enterprises of the TASSR People's Commissariat of Local Industry being in local submission greatly increased. (table №2)

Table № 2. The structure of the district industry of the TASSR People's Commissariat to January 1, 1941 and the conditional changes to September 1, 1941. (NA TR. Col. P-3049. Inv. 6 add. F. 12. L. 1)

\begin{tabular}{|l|c|c|c|}
\hline & On January 1, 1941 & On September 1, 1941 & Growth (in \%) \\
\hline Districts included in the local industry & 29 & 52 & 79 \\
\hline $\begin{array}{l}\text { The number of district industrial plants and } \\
\text { independent production units }\end{array}$ & 34 & 54 & 58,8 \\
\hline The number of productive industries & 17 & 19 & 11,7 \\
\hline The number of productions & 84 & 167 & 98,8 \\
\hline
\end{tabular}

The party bodies paid much attention to the problems of the reception, accommodation and employment of the evacuated people. The department of evacuation of the Council of National Commissioners of the TASSR prosecuted this subject. Only in August 1941 about 57 thousand evacuated people arrived in the republic and at the beginning of September more than 175 thousand people were accommodated (in the spring of 1942 - about 266 thousand people). (Gilmanov 1977, p. $70,77-78$ ) In the ensuing years the stream of evacuated people reduced.

The structural change at the level of ministries and departments began; it was connected with the necessity to fill need in products for the front and the population of the republic in a full measure. However it must be noted that during the 1941-1945 the fundamental changes in the system of control were not made, the reforms had mainly selective character. We believe that there were several reasons for that and the most important were the following:

Firstly, the model of management, formed in the 1930s, and based on the branch principle, centralized management that fitted the conditions of wartime when the orders of higher authorities had to be fulfilled exactly.

Secondly, an insufficient number of managers and specialists connected to the fact that the number of employees in many departments and commissariats was reduced by more than by half (workers were mobilized to the front).

Thirdly, there was the lack of funding of ministries and departments. Allocated funds were not always enough even for the maintenance of workers to say nothing of the labour power industrial intake.

At the initial period of war the republic was represented by the following organizational units: the People's Commissariat of Local Industry of the TASSR, the People's Commissariat of Food Industry of the TASSR, the People's Commissariat of Light Industry of the TASSR, People's Commissariat of Wood Industry of the TASSR, People's Commissariat of Dairy and Meat Industry of the TASSR, the Administration of the local fuel industry of Council of National Commissioners of the TASSR, the Administration of the industry of building materials of the Council of National Commissioners of the TASSR, industrial cooperation and enterprises of the Union and the federal subordination, evacuated to the republic in 1941-1942.

There were clearly differentiated duties of the leaders at all levels in the control system of the republic industry and any deviation from these rules could lead to serious consequences. For example, at the level of the Council of People's Commissars (CPC) of Light Industry of the TASSR, the Administration of the local fuel industry of the CPC of the TASSR, the Administration of the building materials industry of the CPC of the TASSR, enterprises being in federative and union subordination F.M.Kowalsky was in charge; S.M. Sharafeev was the head of the activities of the People's Commissariat of Local Industry the TASSR, the People's Commissariat of Food Industry the TASSR, fish trust and industrial cooperations. (NA TR.. Col. P-6292. Inv. 1. F. 421. L. 95-96) Similar orders were established in the other People's Commissariat, administrations and factories. At the same time throughout the course of the war the degree of responsibility of managers, duties, etc. had a variable character. Thus, in accordance with the order of the People's Commissariat of Local Industry of the TASSR number 185 of 22 November 1941 (NA TR. Col. P-3049. Inv. 5. F. 334. L. $52,53)$ within the people's commissar's competence were such activities as guidance of the economic planning department, of the financial, staff and wage sectors, the special sector, the central accounting, the building materials enterprises of regional subordination and the deputy people's commissar was in charge of the production and technical 
department, the maintenance department, the local industry of supply and sale, all regional enterprises, except for the enterprises of building materials, enterprises of the district industry. By the middle of the war on the basis of the order number 1 on January 4, 1943 (NA TR. Col. P-3049. Inv. 5. F. 401. L. 1) a new division of responsibilities between the people's commissar and his deputy was put into operation: the first was responsible for the enterprises of regional subordination, the economic planning department, the central accounting, the financial sector, the mobilization department and the local industry of supply and sale, and his deputy - for the enterprises of district (city) subordination, the production and technical department, the staff and wage sector, the maintenance department.

Considerable attention was paid to the optimization of the existing departments, agencies, trusts and companies from the side of the operating overhead. Thus due to the resolution of the CPC of the TASSR number 377 of 18 August 1941 "About the staff reduction of people's commissariat, administrations and economic authorities of the TASSR, as well as the elimination of unnecessary administrative units and economic instrument" from September 1, 1941 the staff of all the commissariats, administrations and economic organizations of the TASSR of 689 units was reduced. At the same time the Union of Metal Industry and The Union of Different Industry of the Tatar Industrial Council were combined into a single trade union The Union of Different Industry. (NA TR. Col. P-128. Inv. 1. F. 3476. L. 86)

At the early period of the war in order to bring the industrial leadership to the sources of raw materials some control trustified industries began to transfer from Kazan to some articulate areas. However the result of management activities in the distant areas of Kazan was ineffective. A great amount of problems, mainly organizational, put the brakes to the work of the trustified industry enterprises. For instance, the management of the trust Oil Industry that in July 1941 in accordance with the decision of the CPC of the TASSR was transferred from Kazan to Chistopol. After several weeks of work it became clear that this step had had an extremely negative impact on its activity - the trust turned out to be essentially cut off from the leadership of their organizations and enterprises, located in 47 districts of the Tatar Autonomous Soviet Socialist Republic (only a small part of them had a telephone communication with Chistopol). (NA TR. Col. P-128. Inv. 1. F. 3504. L. 81) A similar situation was observed in the management system of the Tatar Alcohol trust. Having been transferred to Mamadysh, alcohol industry was in a breaking point because the trust could not fix the telephone communication with the subordinate enterprises; the telegraph and post passed through Kazan, as a result the mail reached the enterprises during 3 weeks. As a consequence of the above said the trust's instructions were constantly late. (NA TR. Col. P-128. Inv. 1. F. 3504. L. 91) The executive committee of the Fishtrust were replaced from Kazan to Pestrechinsky District (fish farm "Ushnya"). Here, as in the previous cases, a lot of organizational problems appeared: the trust received the postal bulletins after 8-10 days of waiting, the administrative board renewed by $90 \%$ because of the conscription. Only 8 administrative units existed instead of 18 fixed ones. (NA TR. Col. P-128. Inv. 1. F. 3502. L. 550)

All these resulted in the fact that by the end of the first year of the war a number of administrations was either eliminated or transferred back to the capital of the republic, some of the trusts were reorganized. Thus, in accordance with the resolution of the CPC of the RSFSR № 270/76 from September 19, 1941 the Meat trust was eliminated and its functions were transferred to the People's Commissariat of Meat and Dairy Industry of the TASSR. (NA TR. Col. P-128. Inv. 1. F. 3501. L. 553, 554, 556) As for the Tatar fish it was agreed to transfer it back to Kazan, and since November 1941 in accordance with resolution CPC of the TASSR, in order to reduce administrative expenses it was decided to liquidate it and form the Department of the fishing industry of People's Commissariat of Food Industry of the TASSR. (NA TR. Col. P-128. Inv. 1. F. 3502. L. 549) However, in practice this solution was not carried out.

An important step in reforming the management of industry of the republic in the first year of the war, aimed at creating an effective system of control over the building materials industry, as well as saving funds for the maintenance of excess staff, was done. It was the elimination of the Administration of the building materials industry of the CPC of the TASSR (the order for the CPC of the RSFSR 1445 / 233rs of August 31, 1941 and the Resolution of the CPC of the TASSR number 450 of September 19, 1941 (NA TR. Col. P-128. Inv. 2. F. 3476. L. 242)). Its functions were transferred to the People's Commissariat of Local Industry of the TASSR. However, the errors made in the reorganization of the Commissariat, and, to a greater extent as the loss of control over the activities of the industry led to the fact that during the first half of 1942,the management of construction materials industry of the CPC of the TASSR was reconstructed on the basis of the subdivision of the People's Commissariat of Local Industry of the TASSR.

In the following 1942 the Resolution of the CPC of the RSFSR of October 31, 1942 number 777 and the Resolution of the CPC of the TASSR from November 19, 1942 number 568, of December 1, 1942 the Local Fuel Industry of the CPC of the TASSR was organized on the basis of the District Forestry, Kazan City Fuel Committee) and the Peat regional subordination (Kizichesky and Borisoglebsky).

In accordance with the Resolution of the CPC of the TASSR number 38 of January 29, 1943 "About the organization of peat enterprises in the management of local fuel industry of the CPC of the TASSR " The Resolution of the CPC of the TASSR number 434 of September 29, 1943 as well as the Order of the People's Commissariat of Local 
Industry of the TASSR and management of local fuel industry of the CPC of the TASSR number 20 of February 12, 1943 (NA TR. Col. P-3049. Inv. 5. F. 400. L. 1) 8 peat enterprises were organized - (Aktanysh, Buinsk, Drozhzhanovsk, Zelenodolsk, Naberezhnye Chelny, Savinovo, Chistopol, Yutazy), 6 city fuel factories (Bugulma, Elabuga, Zelenodolsk, Mamadysh , Chistopol, Yutazy). In addition, in January 1944, the regional peat enterprises were organized (Elabuga, Kukmor, Tsipya) and regional fuel factories of district subordination.

Further, based on the Resolution of the CPC of the TASSR number 815 November 10, 1944 and the Order of the People's Commissariat of Local Industry of the RSFSR number 301 in early 1945 the Kizichesky peat enterprise and the Kazan city peat factories were given under the authority of the executive committee of the Kazan City Council. On the basis of government directives and the Orders the People's Commissariat of the RSFSR on fuel № 01-13-26 dated March 3, 1945 and the Order of Head of the local fuel industry of the CPC of the TASSR the number 22 from March 31, 1945 instead of existing in the Management local fuel industry 22 district forest harvesting, 13 peat enterprises, 6 city fuel enterprises were formed 16 wood industrial sectors of district subordination in charge of the Tatar peat trust, 3 city fuel enterprises and 13 district fuel enterprises of district subordination. It should be mentioned that at the postwar period, on the basis of the Resolution of the CPC of the TASSR number 820 of November 17, 1945, from February 7, 1946 Biklyansky, Sheremetyevo wood industry sectors, the Otar peat enterprises were reorganized under the Administration of the local fuel industry with the direct subordination to the Tatar fuel trust.

\section{Conclusion}

Upon the whole, the system of industrial management of the TASSR turned out to be prepared for unexpected enemy aggression; there was not chaos or panic. During the 1941-1945 the series of the operational decisions aimed at the optimization of individual sectors were undertaken through the reorganization of the management personnel. The investigation proved the fact that during the war the restructuring processes touched upon only some operating overheads, the reorganization had a predominantly cosmetic character, which indicated the effectiveness of the sectoral management of the economy of the region that had been created in the prewar period. At the same time these transformation processes had a great effect. In that way the gross industrial output of the Volga republics exceed twice the level of the first half of 1941, and the enterprises of Commissariats military industry increased by 5.6 times (Dyakov U.L. 1988, p. 207). The growth of the gross output during the $1940-1945$ years reached 181\%. Just in1942, the unit weight of the Volga region, the Urals and Siberia in the industrial output increased by 3.3 times in comparison with the pre-war period. The growth rate of the gross output produced by the TASSR industry within 5 years of the war (19411945) achieved 16.95\% (Tatarstan for 50 years 1967, p. 15).

\section{Acknowlegment}

The work is performed according to the Russian Government Program of Competitive Growth of Kazan Federal University

\section{References}

Gilmanov, Z.I. (1977) The TASSR in the Great Patriotic War. 1941-1945. / Z.I.Gilmanov. Kazan, 65.

Dyakov, U.L. (1988) Capital construction in the USSR. 1941-1945. Moscow, 207.

People's Commissariat of Food Industry of the TASSR / The national archives of the Tatarstan Republic (NA TR). Collection (Col.). P6292. Inventory (Inv.) 1. File (F) 286. Leaf (L). 187, 195, 212.

State Planning Commission of the Council of Ministers of the TASSR (State Planning Committee of the Tatarstan) / NA TR. Col. P-4580. Inv. 1. F. 4966. L. 1, 2, 4.

Tatarstan during the Great Patriotic War (1941-1945 гг.). Collection of documents and materials /Authors A.M. Zalyalova, U.I.Smikova, N.A.Subaeva. Kazan, 1963.

Tatarstan for 50 years. Statistical compendium (1967) Kazan, 15.

The Commissariat-Ministry of Local Industry of the TASSR / NA TR. Col. P-3049.

The Council of Ministers of the TASSR / NA TR. Col. P-128.

The Council of national economy of the Tatar economic region. / NA TR. Col. P-7233. Inv. 1. F. 4666. L. 115.

The Directives of the CPSU and the Soviet Government on economic questions (1957) Moscow, 707-712.

The People's Commissariat of Food Industry of the TASSR / NA TR.. Col. P-6292. Inv. 1. F. 421. L. 95-96.

The Red Tatarstan (1942. January 7).

The Red Tatarstan. (1942. July 10). 